\title{
Visszapillantás a transzmissziós elektronmikroszkópia (TEM) módszerek ásványtani és földtani alkalmazásának hazai történetére (1970-2020)
}

\author{
DóDONY István
}

Pannon Egyetem, NANOLAB, Veszprém, Egyetem u. 10.

\section{Recollections on the applications of transmission electron microscopy (TEM) methods in Hungarian mineralogy and geology (1970-2020)}

Abstract

TEM methods have played an important role in mineralogical research and earth sciences over more than seven decades, and the impact of TEM continues to increase exponentially. There is no single technique which has contributed more to our knowledge on the texture, real structure, and the chemistry of matter at the highest spatial, and temporal resolution than TEM. Hungarian mineralogists started to use TEM in the 1970s and at that time introduced the topic into the curriculum at Eötvös University, Budapest. This short paper does not intend to look at the nature of TEM itself but is rather an inventory of the results obtained using TEM methods in Hungarian mineralogical and geological research in the period between 1970 and 2020.

Keywords: mineralogy, transmission electron microscopy, history of science, 1970-2020, Hungary

Összefoglalás

Az anyagvizsgálati eszközök és módszerek alkalmazása terén a TEM uralkodóvá vált a természettudományok orvosbiológiától meteoritikáig terjedő skáláján. Nincs egyetlen olyan módszer sem, amely nagyobb mértékben növelte volna ismereteink minőségét és mennyiségét az anyagok szerkezetéről, összetételéról, egymással való kapcsolatairól, elektromos és mágneses tulajdonságairól, mindezek változásáról a legnagyobb tér- és időbeli fölbontás mellett, mint a TEM. Az itt dokumentált történet az ásványtani TEM-vizsgálatok hazai eseményeinek összefoglalása.

Kulcsszavak: ásványtan, transzmissziós elektronmikroszkópia, tudománytörténet, 1970-2020, Magyarország

\section{Bevezetés}

Jelen jubileumi kötet témáinak tervezésekor az általánosabb „elektronoptikai módszerek” munkacím szerepelt, de a téma illetékesség okán a TEM-es módszerek ásványtani és földtani alkalmazása fejlődésének bemutatására szúkült. Ez a bemutatás nem sztorizó, inkább leltár jellegú, ami nem ígér könnyed olvashatóságot. Publikációink dokumentálják a TEM hazai alkalmazásának történetét azt ásványtanban és a földtanban. A TEM-mel rokon pásztázó elektronmikroszkópia (SEM) és a hullámhosszdiszperzív elemanalízis (WDS) hazai fejlődését tárgyalni a korábbi MTA Geokémiai Kutatólaboratórium (GKL) kutatói hivatottak. Jelen írásban röviden, de hivatkozhatóan próbálom dokumentálni a címben jelzett munkákat.

\section{Kezdetek}

A TEM-nek születésétől (KNOLL \& RUSKA 1932, RUSKA et al. 1939) kezdve tárgya az élő és a szervetlen anyag, köztük az ásványi is. A „mikroszondák” elterjedése és hazai megjelenése könnyítette a TEM alkalmazásának terjedését az ásványtani, földtani kutatásokban. Az egyetemek szilárdtest-fizikai, biológiai és orvosbiológiai tanszékein, az MTA kutatóintézeteiben (pl. MTA Kísérleti Orvostudományi Kutatóintézet, MTA Mûszzaki Fizikai Kutatóintézet), valamint az ágazati kutatóintézetekben (1975-ig Fémipari Kutató Intézet, azután ALUTERV-FKI) a transzmissziós elektronmikroszkópok az 1960-as évekre már rutin vizsgálati eszközzé váltak. Csak a VIII. kerületben (az Üllői út mindkét oldalát ide véve) 12 TEM-berendezés múködött a 70-es 
évek közepén. Ebből látható, hogy más tudományágak (anyagtudomány, biológia stb.) milyen intenzíven és eredményesen használták a módszert saját területükön. Ilyen tudományos, infrastrukturális közegben kezdődhettek meg a TEM-vizsgálatok az ásványtanban, földtanban.

A földtani kutatásokban 1970-től — FüLöP József döntése eredményeként — az ELTE TTK-n indulhatott a transzmissziós elektronmikroszkópia alkalmazása a kutatásban. A beszerzett JEOL-100U TEM sokáig ládában állt a Múzeum körúti A épület előtt, az 1971-es installációját követően 1973-ban kapta meg múködési engedélyét. A labor szervezetileg az ELTE Általános Földtani Tanszékén múködő MTA-kutatócsoporthoz tartozott, de az ELTE Ásványtani Tanszék területén volt. Az új TEM-labor vezetôje, IBRÁNYINÉ ÁRKOSI Klára és technikusa, RUDNYÁNSZKY Lívia az ELTE TTK-n múködő, ERDEY-GRÚZ Tibor vezette MTA-kutatócsoportból érkezett. Hozzájuk csatlakozott az 1968-ban diplomázott DÁvID Klára geológus, később MORLIN Jánosné technikus. IBRÁNYINÉ ÁRKOSI Klára kandidátusi értekezésében „Hazai agyagásványok elektronmikroszkópos és elektrondiffrakciós vizsgálata (1968)" címmel foglalta össze hazai és orléans-i tanulmányútján elért eredményeit. Az 1970-es évek elején IBRÁNYINÉ ÁRKOSI Klára megcélozta az elektrondiffrakció alkalmazását, de említhetô eredmények nem születtek. Az agyagásványvizsgálatok 70-es évekbeni helyzetéról VoGL (1981) adott részletekbe menő áttekintést egy 1981-ben megjelent összegző írásában, éppen a Földtani Közlöny hasábjain. IBRÁNYINÉ ÁRKOSI Klára 1972-tôl bekapcsolódott az egyetemi oktatásba, 1973 őszi szemeszterében NAGYMAROSY Andrással közösen vettük föl az „Elektronmikroszkópos vizsgálatok az ásványtani kutatásban” címú speciális kollégiumot.

1973-tól az Ásványtani Tanszéken fokozatosan növekedtek az igények a TEM használatára. 1974-ben már a KISS János tanszékvezető mellett diplomamunkáján dolgozó HARTAI Éva, az akkor fiatal tudományos segédmunkatárs (jelen szerző), valamint emlékem szerint még a KőzettanGeokémiai Tanszéken 1973-ban diplomázó PusKás Zuárd heti rendszerességgel adtak munkát a labornak és tevékenykedtek ott. Kiss János HARTAI Évát kérte/szánta IBRÁNYINÉ ÁRKOSI Klára utódjának, amit Éva személyes okokból nem vállalt. Ekkor, ellenkezésem dacára, én kerültem „célkeresztbe”. A — vélhetôen — mérésszolgáltatói feladatkör nem tûnt számomra kívánatos perspektívának. A parádsasvári paligorszkiton végzett elektrondiffrakciós munka (DóDONy 1976, DóDONY \& Kiss 1976) gyöngítette pozíciómat. Győzött a tanszékvezető, „duzzogva” vállaltam a TEM múvelését. Mára már szép emlékké nemesült ez a turbulens periódus. 1978-ra az ELTE Ásványtani Tanszékére került a TEM-labor. Állandó személyzetként RuDNYÁNSZKY Lívia, MoRLin Jánosné és magam voltunk, de a jelenlévő TDK-zó, diplomamunkán, disszertáción dolgozó hallgatók egyenrangú társak voltak a közösen megfogalmazott célok elérésében. KISS János tanszékvezetése alatt a TEM-labort érintő törekvések (például szakkönyvbeszerzés, eszközfejlesztés stb.) — ha csatá- rozások eredményeként is — mindig támogatást kaptak, a Kiss Jánosét követő időszakról ezt nem mondhatom. Az elmúlt évtizedek tapasztalata alapján a tanszéki kollégák közül a LovAs Györggyel való együttmúködést hangsúlyozom.

A labor múködtetése során három célt fogalmaztunk meg:

1. Megismerni a szakterület aktuális eredményeit, képessé válni azokat reprodukálni és alkalmazni még föltáratlan területeken.

2. Az ásványtan oktatásába bevonni a TEM nyújtotta kristálytani, kristálykémiai ismereteket.

3. Az ásványtanon kívüli területeken is alkalmazni a megszerzett ismereteket és gyakorlatot.

\section{Sikerek}

1976 tájékán a vezetô, anyagtudománnyal kapcsolatos folyóiratok és tudományos könyvek „sztártémája” a nagy felbontású transzmissziós elektronmikroszkópia (HRTEM) és annak technikája volt. Ennek megfelelően sorban adták közre a téma új eredményeit (IIJIMA 1975, WENK 1976, COWLEY \& IIJIMA 1976). A vezető laboratóriumokban megvalósult a kristályszerkezetek vizuális megfigyelhetôsége atomi felbontással, valamint a kísérleti megfigyelések kristályszerkezeti értelmezésének számításokkal történő hitelesítése (SKARNULIS et al. 1976). Mindez akkor még idegennek tûnt köreinkben.

Hogy tudatlanságunkból kilépjünk, a transzmissziós elektronmikroszkópia és a HRTEM témájában speciális előadásokat szerveztünk tanszéki érdeklődőknek, ezeket az ALUTERV-FKI antwerpeni tanulmányútjáról visszatért CsOrdÁs Anna (ma PINTÉRné CsORDÁs Anna) tartotta, időnként munkahelyi fơnöke, GADó Pál részvételével. 1977ben az MTA Múszerügyi Szolgálat akciójában került egy JEOL-100CX TEM-berendezés az akkori ORFI kórház Neumark Tamás vezette Szövettani Osztályára. Ennek a mikroszkópnak a felbontóképessége a gyakorlatban kicsit jobb volt, mint $4 \AA$ A Múszerügyi Szolgálat (WEISzBURG János) támogatásával heti rendszerességû hozzáférést kaptam a múszerhez, „,cserében” biopsziákat, porc- és csontmintákat is vizsgáltam. Ez a kapcsolat a rendszerváltásig múködött, itt szerezhettem meg a mikroszkópia rutinját, köszönet érte. A HRTEM minőségében — kimerítve a JEOL-100CX TEM-berendezés kapacitását — közelítettuik a kor 3-4 Å körüli felbontási érték korlátját. Eredményeink visszaigazolását és kontrollját keresve hazai és nemzetközi konferenciákon szerepeltünk (DóDONY 1979a, b, c; DóDONY \& WeISZBURG 1979), hazai szakmai visszajelzést alig kaptunk — úttörôk lévén a szakterületen —, külföldi kollégák azonban nagyon pozitívan vélekedtek eredményeinkről.

Az anyag-elektron kölcsönhatás részleteit 1957-től kezdődően COWLEY \& MoODIE (1957) két évtized alatt tárta föl és írta le. Ez nyitott kaput arra, hogy a HRTEM-képeket kvantitatívan értékelhessük. SKARNULIS et al. (1976) számítógépes programcsomagot adtak mindarra, ami össze- 
vethetővé teszi a kísérleti HRTEM-képeket egy kristályszerkezeti modellel és a kísérleti elektronoptikai adatokra szimulált képpel. A HRTEM-képek értelmezésének hitelesítésére a mai napig a HRTEM-képek ilyetén szimulálása szolgál. A kísérleti paraméterek ismeretében számítható egy HRTEM-kép az értelmezett kristályszerkezeti modellel, és ha a kísérleti és a szimulált kép az elfogadhatósági határig egyezô, akkor az értelmezés (a szerkezet) helytálló.

A számítógépes háttér fejlesztésével szinkronban értük el SKARNULIS programcsomagját, és LovAS Györggyel együttmúködve kialakult a programcsomag használatának rutinja. 1980-ra nemzetközi szinten elismert szakértők (J. Van Landuyt, Antwerpen és J. S. Anderson, Oxford), valamint a hazai szakma illetékes képviselói (Magyar Diffrakciós Társaság) előtt sikerrel szerepeltünk HRTEMképeink értelmezésének szimulációk útján végzett hitelesítésével (BognÁR et al. 1980, DóDONY \& LovAs 1980). A 8th European Congress on Electron Microscopy rendezvényei 1984-ben hazánkban zajlottak, ahol — nem csak a magunk mércéjével — sikerrel szerepeltünk (DóDONY \& MALEeV 1984, DódONY \& Soós 1984, DóDONY et al. 1984). A nyolcvanas években szaporodtak és minőségileg javultak az elektrondiffrakciós és nagy felbontástású technikákat használó megfigyeléseink (DóDONY 1980, 1982, 1985a, b, 1986, 1987; DóDONY \& LOVAS, 1982a, b, 1983; MINDSZENTY et al. 1986), miközben a törekvéseink súlypontja az oktatás felé tolódott. 1987-ben jelent meg STADELMANN (1987) EMS-programcsomagja, amely elektrondiffrakciós felvételek és HRTEM-képek szimulációját szolgálta. Ez a programcsomag, a folyamatos fejlesztésének köszönhetően, a TEM-es mérések szimulációjának és értékelésének máig egyik legjobb eszköze.

A perovszkit alapszerkezetú kerámiák szupravezetését felismeró publikációt (BEDNORZ \& MüLLER 1986) követően, aki adott magára, ilyen anyagok vizsgálatával foglalkozott. Engem KIRSCHNER István először 1989-ben hívott egy közös, finnországi (Oului Egyetem) Eurekaprojektben végzendố munkára, a szupravezetô kerámiarétegek szintetizálására és transzmissziós elektronmikroszkópos vizsgálatára (KIRSCHNER et al. 1990, 1991, 1993a, b; HAGBerg et al. 1990; KÁRMÁn et al. 1990; UUSIMAKI et al. 1990; DóDONY et al. 1991; LEPPAVUORI et al. 1992). Ez a cikkdömping számomra újdonság volt, amit a mai napig sem kedvelek.

Az 1990-es években eredményeink értéke nőtt, több tekintélyes folyóirat közölte az ez idő tájt született munkáinkat, ezeket a mai napig hivatkozzák és idézik. A mintaelôkészítést forradalmian megújította a MFKI („MÜFI”)-ből beszerzett („BARNA Árpád-féle”) ionbombázásos vékonyító, melynek segítségével vékony (>100 Å), elektrontranszparens keresztmetszeti mintákat készíthettünk törékeny, hasadó anyagokból (pl. csillám, azbeszt) is. 1993-ban a középeurópai országok mikroszkópos társaságainak konferenciája Pármában volt, ahol a szerpentinitek mikroszerkezetéről tartottam előadást (DóDONY 1993) (a lizardit szerkezetét meghatározó Marcello MelLinivel is diskurálhattam). Az itt megmutatott anyag több, szerpentinásvánnyal foglalkozó

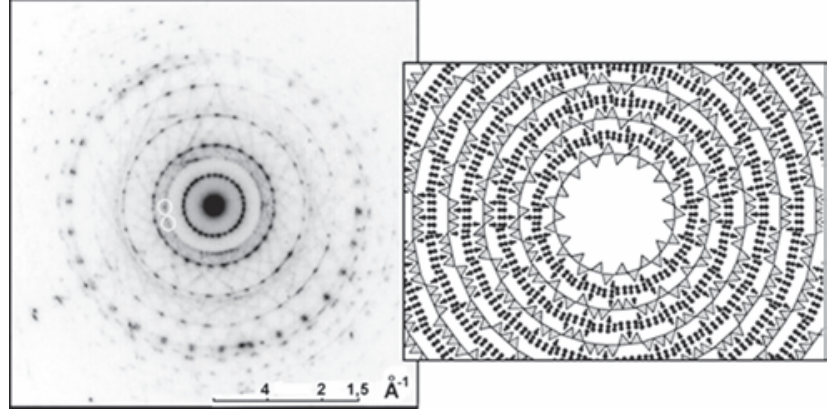

1. ábra. A 30-szektoros poligonális szerpentin határolt területű elektrondiffrakciós felvétele és kristályszerkezetének modellje, a szürke háromszögek a szilikáttetraédereket, a fekete pöttyök a Mg-központú oktaéderes réteget mutatják (DóDONY 1993)

Figure 1. Selected area electron diffraction pattern (on the left) and the corresponding structural model (on the right) of a 30-sectored polygonal serpentine (DóDONY 1993). The gray triangles and black dots indicate the silicate tetrahedra and Mg-centered octahedral sheets, respectively

munkánk startköve volt. Az 1. ábra a poligonális szerpentin tengely irányú elektrondiffrakciós felvételének képét és kristályszerkezeti modelljét mutatja.

Egy lemezes szerkezetú, így kitúnően hasadó új ásványfaj, a buckhornit szerkezetét az ionbombázásos vékonyítónak köszönhetően sikerült elektrondiffrakciós felvételek alapján jellemeznünk (JoHAN et al. 1994). A most fontosnak mondottak mellett több rutinmunka is eredménnyel zárult (SzAKÁLL et al. 1994a, b, 1995, 1997; LOVAS \& DóDONY 1997; LÁBÁR et al. 1998; PAPP et al. 1999).

Az optikailag anizotrop grosszulár-andradit elegysor recski példányain azonosítottuk az anizotrópia kristályszerkezeti eredetét (DóDONY et al. 1994a, b). A Szervetlen Kémiai Tanszék munkatársával és doktoranduszával vizsgáltuk az optoelektronikában jelentős bizmut-tellurát szerkezeteit (SzALLER et al. 1996; LovAS et al. 1998; lásd. 2. ábra). A pirit-markazit szerkezeti kapcsolatát tisztázó munka (DóDONY et al. 1996) a mai napig élő kutatási témákban idézett eredménynek bizonyult. A lizarditpolitípek listázása és diffrakciós sajátosságaik jellemzése fontossá vált a 2000-es évek munkáiban (DóDONY 1997a).

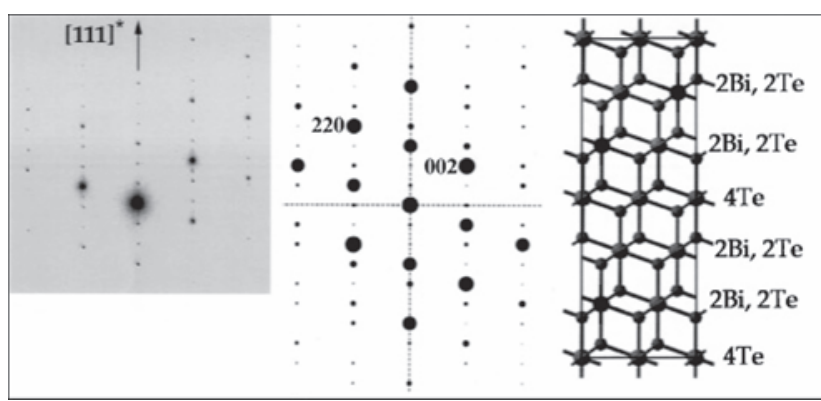

2. ábra. A fluoritrokon szerkezetű $\mathrm{Bi}_{2} \mathrm{Te}_{4} \mathrm{O}_{11}[1-10]$ vetületű kísérleti (balra) és számított elektrondiffrakciós felvétele (középen), és a szerkezeti modell egy elemi cellája (jobbra)

Figure 2. Experimental (left) and simulated (middle) electron diffraction patterns of the fluorite-stuffed $\mathrm{Bi}_{2} \mathrm{Te}_{4} \mathrm{O}_{I I}$ in the [1-10] projection. The structural model is on the right 
A szerpentinitek gyakori, de kevésbé ismert komponense, a korábban már bemutatott (DóDONY et al. 1993) poligonális szerpentin szerkezeti modelljét a szélesebb nemzetközi szakmai közvélemény 1997-ben ismerhette meg (DóDONY 1997b).

1999-ig a kollégákkal intenzíven dolgoztunk a fullerénkomplexek szerkezeti és kristálykémiai aspektusainak

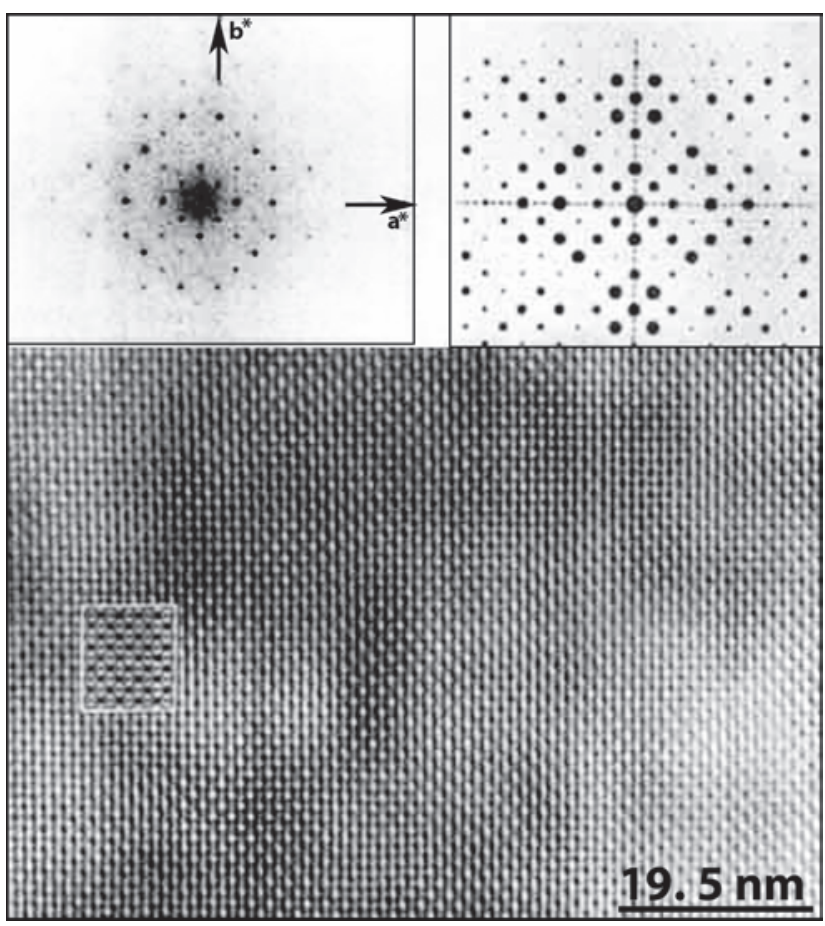

3. ábra. Egy $\mathrm{C}_{60} \mathrm{~S}_{16}$ kristály [001] vetületű kísérleti (balra fönt) és szimulált (jobbra fönt) elektrondiffrakciós felvétele. A [001] vetületű kísérleti és a szimulált HRTEM-kép (fehéren keretezve) illeszkedése kielégítő

Figure 3. Experimental (top left) and simulated (top right) electron diffraction patterns of a $C_{60} S_{16}$ crystal in [001] projection. The match of the experimental and the inserted calculated HRTEM image (bottom) is satisfactory

tisztázásán (LOVAS et al. 1999a, b; RAUSCH et al. 1999a, b). Kiderült, hogy a kén hogyan alkot molekularácsú komplexet a Buckminster $\mathrm{C}_{60}$ fullerénnel (3. ábra)

Az 1990-es évek elején a tulajdoni és szervezeti viszonyok körüli turbulenciákban véget ért a JEOL-100CX TEM-hez való hozzáférés az ORFI-ban. Az ORFI Szövettani Osztályán az addig diagnosztikai és terápiás célú csontés porcvizsgálatok kutatási célúvá váltak, és heti rendszerességgel az ELTE Ásványtani Tanszékén az öreg (már Rosinante becenevú) 100U berendezésen folytatódtak. De 2000-re gyakorlatilag véget ért a JEOL-100U TEM-labor múködése is, mára múzeumi egységgé vált az ELTE TTK-n. Az ásványtani-földtani kutatások az MTA EK Vékonyréteg Osztályán múködtetett Philips CM20 és JEOL 3010 TEMberendezéseken és külföldön folytatódhattak. Számomra termékeny négy és fél évet töltöttem a TEM — John COWLEY-val fémjelzett — „Mekkájában”, az Arizonai Állami Egyetemen (ASU, Phoenix, Tempe), az ott készült munkáink mai mércével mérve is helytállók (DóDONY \&
BUSECK 2001, 2004a, b; DóDONY et al. 2002, 2006; KONISHI et al. 2002, 2003; ZEGA et al. 2004, 2006). Ezek mellett sikerült a hazai munkákkal is kapcsolatban maradni (KovÁCs KIs \& DódONy 1999; LÁBÁR et al. 2000; KovÁCS KIs et al. 2006).

2000-től számítva az ELTE TTK Ásványtani Tanszék központi szerepe csökkent a TEM ásványtani, földtani alkalmazásában. Ennek a változásnak van örömteli oldala is, hiszen a tanszéken képzett kollégák más intézetekben elért eredményei visszaigazolják az oktatás hatékonyságát. De ha például 1990 táján Soós Miklós, PAPP Gábor és PÓSFAI Mihály, akik az idô tájt dolgoztak doktori munkáikon a tanszék TEM-laborjában, az ELTE-n maradhattak volna, akkor az elmúlt három évtizedben nem lett volna TEM-mentes az ELTE-n a kutatás.

A mikroszkópia gyakorlatát az Ásványtani Tanszéken megismerő volt hallgatók kiváló képviselői között KovÁCSNÉ KIS Viktóriát (ELKH EK MFA), NÉMETH Pétert (ELKH TTK AKI) és CORA Ildikót (ELKH EK MFA) említve láthatjuk, hogy munkáik jelentős hányada a mai napig ásványtani, földtani (MTMT alapján a nevek fenti sorrendjében: 58/90, 31/63 illetve 23/57). 1991-ig hallgatónk és munkatársunk volt PóSFAI Mihály, az ő munkáit itt nem illesztem a hazai TEM ásványtani-földtani alkalmazásának áttekintésébe, az ô szakmai történetének és eredményeinek bemutatása meghaladja e rövid áttekintés kereteit (lásd PÓSFAI 2016).

Századunkban a TEM fejlődését az elektronkrisztallográfia (Zou 2005, DóDONy \& CoRA 2014) és a pásztázó transzmissziós elektronmikroszkópia (STEM) térhódítása jellemzi. Ez számos új hardver (érzékeny és lineárisan mérő detektorok, kamerák; krio-rendszerek stb.) és szoftver (ptychográfia, „compressed sensing”, tomográfia, holográfia, elektronsugaras direkt módszerek stb.) kifejlesztésével és bevezetésével járt (BÉCHÉ 2016, HAWKES \& SPENCE 2019, PENNYCOOK et al. 2019).

A STEM mára lehetőséget biztosít egyedi atomok lokalizálására és azonosítására, sôt azok együttesének 3D leképezésére is. Az elemtérképezésre jó példát ad SCHAFFER et al. (2011) munkája, amelyben a $\mathrm{Ba}_{6-3 x} \mathrm{Nd}_{8+2 x} \mathrm{Ti}_{18} \mathrm{O}_{54}$ alkotóinak atomi fölbontású rendszámarányos kontrasztú (a

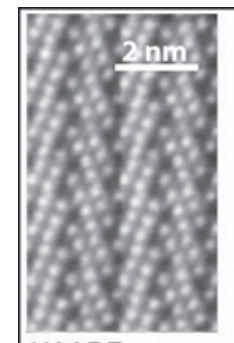

HAADF

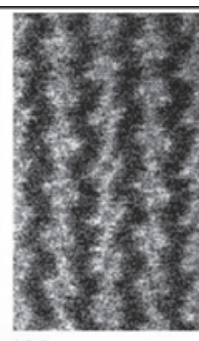

Nd map

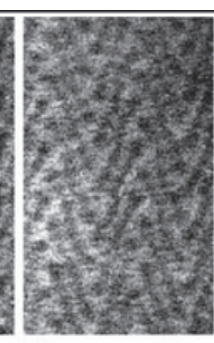

Ti map

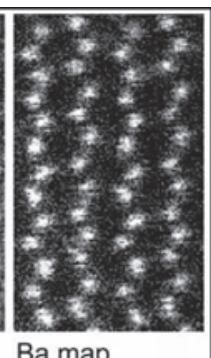

Ba map
4. ábra. Nagy fölbontású - STEM HAADF - kép $\mathrm{Ba}_{6-3 \mathrm{x}} \mathrm{Nd}_{8+2 \mathrm{x}} \mathrm{Ti}_{18} \mathrm{O}_{54}$ kristályról és az egyes alkotók elemtérképei EELS-spektrumok alapján (SCHAFFER et al. 2011 után)

Figure 4. High resolution $\mathrm{HAADF}$ image of $\mathrm{Ba}_{6-3 \mathrm{x}} \mathrm{Nd}_{8+2 x} \mathrm{Ti}_{18} \mathrm{O}_{54}$ crystal and elemental maps for Nd, Ti and Ba derived from STEM EELS. (after SCHAFFER et al. 2011) 
Rutherford-szórást detektáló) HAADF-képét és az egyes elemek elektron-energiaveszteséges spektroszkópiával alkotott térképeit mutatja (4. ábra).

A negyedik dimenzió, az idő is mikroszkopizálhatóvá vált. A kémiai és szerkezetátalakulási folyamatok leképezésének tér- és időbeli felbontása a $\mathrm{H}^{+}$ion megfigyelhetősége mellett (CLABbERS et al. 2019), idóben az atto- és femtoszekundumos tartományban van (FLANNIGAN \& LiNDENBERG 2018).

A szöveti, orientációs és fáziseloszlás-térképezés a nanométeres tartományban is rutineljárássá vált (RAUCH et al. 2010). Az orientációs térképezés eszközeit és programcsomagját (NanoMegas ASTAR) az akkori Bay-Nano (Miskolc) intézetben beszereztük és eredményesen kezdtük használni (RONTÓ et al. 2013; BIRÓ et al. 2014; BARNA et al. 2019), de az alapítványok közös sorsa (2010-et követően az alapítványok zöme megszúnt/átalakult) véget vetett az ASTAR hazai alkalmazásának. TEM-ben a lokális feszültség és deformáció is szub-Å fölbontással vizsgálható (1. például GALINDO et al. 2007; WANG et al. 2015). Mi a geometriai fáziselemzés technikáját alkalmazva rácshibát vizsgáltunk piritben (NÉMETH et al. 2013), ahol a deformációt (elmozdulásértékeket) mértük (5. ábra).

A szervetlen anyagok hazai elektronkrisztallográfiai eredményei — köreinkben — jelentôsnek mondhatók. Az ICSD (Inorganic Crystal Structure Database) szerkezeti adatbázisában 2016-tal bezárólag nyolc kristályszerkezet meghatározásunk szerepel. Azóta születtek még említést érdemlő újabb szerkezetmeghatározásaink transzmissziós elektronmikroszkópos technikák alkalmazásával (pl. DóDONY et al. 2012; CoRA et al. 2014, 2015, 2017; DodOny et al. 2019), de 2016-tól megszúnt az adatbázishoz való további hozzáférésünk.

Az oktatást a végzett hallgatók eredményei minősítik. Elfogulatlan értékelést személyes érintettségem miatt nem

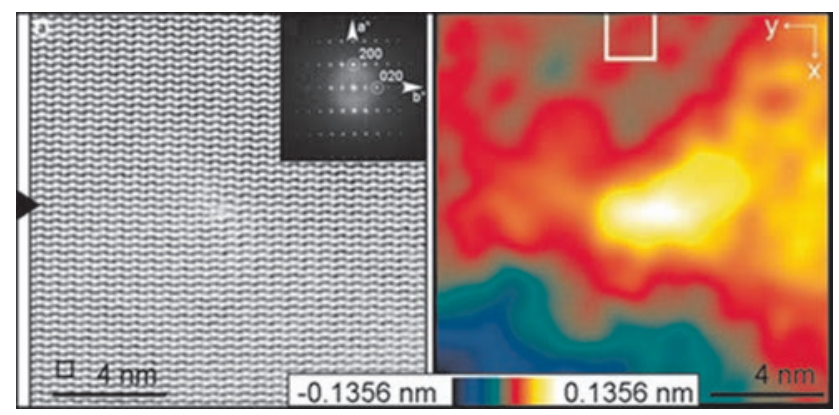

5. ábra. Pirit [001] vetületű HRTEM-képe (balra) és annak Fourier-transzformja. Egy éldiszlokációt idézően végződő rácssíkot fekete nyílhegy mutat balról. Jobbra az ideális szerkezeti pozíciókhoz viszonyított elmozdulás értékeket mutatja az ábra alján lévő - léptékkel jelzett - színskála (NÉMETH et al. 2013 után)

Figure 5. [001] projected HRTEM image of pyrite (on the left) and its Fourier transform (inserted). The black arrowhead points to a virtual edge dislocation, which terminates in the middle of the HRTEM image. On the image of the experimental uy displacement field (on the right) around the termination, the colour at a given place represents the value of displacement along $y$, referred to the ideal (undeformed) position. The colour range is from 0 to $0.2714 \mathrm{~nm}$. (after NÉMETH et al. 2013, coloured in online) adhatok, de néhány kolléga — TEM-módszerekkel elért eredményeit kirakatba lehet tenni. Többek közt Soós Miklós, PAPP Gábor, Pósfai Mihály, KIs Viktória, NÉMETH Péter, PEKKER Péter, CORA Ildikó tevékenysége jelenleg is visszaigazolja az oktatásban kitúzött céljaink megvalósulását. Nem tudom szó nélkül hagyni, hogy a néhány évtizeddel korábbi feladatok megoldását a mai hallgatók átlagától elvárni reménytelen.

$\mathrm{Az}$ egyetemi oktatás legintenzívebb formája a közös kutatómunka és az eredmények közös publikálása (a teljesség igénye nélkül: DALlos et al. 2020; DóDONY \& BALOG 1982; DódONy \& PÓSFAi 1989; DóDONY \& TAKÁCS 1980, 1982, 1986; DÓDONY \& WEISZBURG 1971, 1982, 1983; KovÁCs-KIs \& DóDONY 1999, 2003, 2004; DóDONY et al. 2003; KovÁCs-Kis et al. 2004; MenYhÁRT et al. 2011; ORMÁNDI \& DóDONY 2016; PÓSFAI \& DóDONY 1990; Soós \& DóDONY 1989; Soós et al. 1991 ).

Az ásványtannal szoros kapcsolatban nem lévő területeken is alkalmaztuk a TEM-et, a korábban említett szupravezető anyagok mellett építőanyagok, katalizátorok, talajok, pegmatitok és metamorfitok vizsgálatában (DóDONY 1981, Petró et al. 2000, Sipos et al. 2005, BermaneC et al. 2012, ÁrKAi et al. 2012, NÉMETH et al. 2016, ORMÁNDI \& DóDONy 2016), számos kutatási jelentésünket itt nem sorolom.

\section{Remények}

Az elektronoptikai módszerek témájú kurzusokat lezáró, majd a gyakorlati oktatást eredménnyel végző hallgatók zöme, ha nem is dolgozik közvetlenül TEM-témákban, de a maguk területén is közvetlen hatással van a TEMes alkalmazások elterjedésére. Például Soós Miklós cégével (Auro-Science Kft.) a Nikon, a FEI, az Oxford Instruments és számos más nagy mikroszkópgyártó hivatalos hazai képviselője, a Magyar Mikroszkópos Társaság mecénása. A jövôt tekintve nagy bizalommal lehetünk a Pannon Egyetemen múködő, PósFAI Mihály vezette NANOLAB (http://nanolab.uni-pannon.hu/) tevékenységét illetően. A 2018 óta múködő Talos F200X G2 (S)TEM (Thermo Scientific (FEI)) mikroszkóp és a körülötte lévô, arányosan kialakított infrastruktúra, valamint a munkatársak képessége és motiváltsága ígéretes. A földtani kutatásokat múvelők körében lassan, de folytonosan nő azok száma (és szakmai súlya), akik fölismerték a TEM-STEM szerepét az analitikában és a reális kristályszerkezetek 3D-s jellemzésében.

Talán nem szerénytelenség ezt az összegzést azzal zárni, hogy közel öt évtizeddel ezelőtt sikeresen kezdtünk fölzárkózni a TEM-alkalmazások világszínvonalához, majd lépést tartottunk a módszer robbanásszerú fejlődésével. Az egyetemi képzés sikerét igazolja, hogy kollégáink egyre szorosabbra füzik az együttmúködést a földtani gyökerú ásványtani vizsgálatok és a hazai anyagtudomány központjai (MTA Energiatudományi Kutatóközpont, MTA Természettudományi Kutatóközpont) között. A Pannon Egyetem NANOLAB Környezeti Ásványtan Kutatócsoporttal 
együttmúködő külföldi és hazai intézetek és kutatási témák spektruma reális képet ad az ásványtan és TEM kapcsolatáról (lásd a Nanolab honlapon a Témák/Felhasználók alatti témákat). Az intézetek/témák száma: Földtudományok 12/15, Anyagtudomány/Nanotechnológia 5/12, Kémia L, Biológia 4/5, Alkalmazott kutatás 3/3.

\section{Köszönetnyilvánítás}

Köszönöm KovÁcs KIs Viktória, NÉMETH Tibor, PAPP Gábor és PÓSFAI Mihály konstruktív kritikáját és segítségét eme rövid munka szövegezésében.

\section{Irodalom — References}

Árkai, P., Abad, I., Nieto, F., Németh, T., Horváth, P., Kis, V., Judik, K. \& JimÉnez-Millán, J. 2012: Retrograde alterations of pyllosilicates in low-grade metapelite: a case study from the Szendró Paleozoic, NE-Hungary. — Swiss Journal of Geosciences 105, 263-282., https://doi.org/10.1007/s00015-012-0097-1

Barna, P. B., Biro, D. F., Hasaneen, M., Székely, L., Menyhárd, M., Sulyok, A., Horváth, Z. E., Pekker, P., Dódony, I. \& Radnóczi, G. 2019: Cross sectional complex structure analysis is a key issue of thin film research: A case study on the preferential orientation crossover in TiN thin films. — Thin Solid Films 688, 31 October 2019, 9 p., https://doi.org/10.1016/j.tsf.2019.137478

BednorZ, J. G. \& MÜLLER, K. A. 1986: Possible High Tc Superconductivity in the Ba-La-Cu-O System. — Zeitschrift für Physik B Condensed Matter 64, 189-193.

Béché, A., Goris, B., FreitAG, B. \& VerbeEck, J. 2016: Development of a fast electromagnetic beam blanker for compressed sensing in scanning transmission electron microscopy. — Applied Physics Letters 108, 093103, https://doi.org/10.1063/1.4943086

Bermanec, V., Horvat, M., Gobac, Z. Z., Zebec, V., Scholz, R., Skoda, R., de Britto Barreto, S. \& Dódony, I. 2012: Pseudomorphs of low microcline after adularia fourlings from the Alto da Cabeca (Boquueirao) and Morro Redondo pegmatites, Brazil. — The Canadian Mineralogist 50, 975-987., https://doi.org/10.3749/canmin.50.4.975

Biró, D., Hasaneen, M. P., Székely, L., Menyhárd, M., Gurbán, S., Pekker, P., Dódony, I. \& Barna, P. B. 2014: Texture change of TiN films due to anisotropic incorporation of oxygen. — Vacuum 103, 78-86., https://doi.org/10.1016/j.vacuum.2013.12.013

Bognár, L., Dódony, I. \& Lovas, A. Gy. 1980: Crystalline phases forming Kaolinite-CaO system at various temperatures and compositions. Real structure of gehlenite. - X. Hungarian Diffraction Conference, 25-30 April, 1980 Balatonaliga. Collected Abstracts.

Clabbers, Max T. B, Gruene, T., van Genderen, E. \& Abrahams, J. P. 2019: Reducing dynamical electron scattering reveals hydrogen atoms. - Acta Crystallographica A 75, 82-93., https://doi.org/10.1107/s2053273318013918

CoRA, I., Dódony, I. \& PeKKeR, P. 2014: Electron crystallographic study of a kaolinite single crystal. — Applied Clay Science 90, 6-10., https://doi.org/10.1016/j.clay.2013.12.034

Cora, I., PekKer, P., Dódony, I. \& Janovszky, D. 2015: Single crystal structure determination and refinement of $\mathrm{AgZrCu} \mathrm{and}_{4} \mathrm{Ag}$ containing $\mathrm{Cu}_{10} \mathrm{Zr}_{7}$ by precession electron diffraction and tomography techniques. - Journal of Alloys and Compounds 658, 678683., https://doi.org/10.1016/j.jallcom.2015.10.230

Cora, I., Mezzadri, F., Boschi, F., Bosi, M., Čaplovičová, M., Calestani, G., Dódony, I., Pécz, B. \& Fornaric, R. 2017: The real structure of $\varepsilon-\mathrm{Ga}_{2} \mathrm{O}_{3}$ and its relation to $\kappa$-phase. - CrystEngComm 19, 1509-1516., https://doi.org/10.1039/c7ce00123a

Cowley, J. M. \& IJImA, S. 1976: The Direct Imaging of Crystal Structures. In: Wenk, H.-R. (Coord. ed.): Electron Microscopy in Mineralogy. — Springer Verlag Berlin, Heidelberg, New York, 123-136., https://doi.org/10.1007/978-3-642-66196-9_6

Cowley, J. M. \& MoodIE, A. F. 1957: The Scattering of Electrons by Atoms and Crystals. I. A New Theoretical Approach. - Acta Crystallographica 10, 609-619., https://doi.org/10.1107/s0365110x57002194

Dallos, Zs., Kovács Kis, V., Kristály, F. \& DóDony, I. 2020: Leaching mechanism of bioapatite in carbonate saturated water. CrystEngComm 22, 2788-2792., https://doi.org/ 10.1039/C9CE01228A

DodOnY, E., RADNócZI, Gy. Z. \& DóDONY, I. 2019: Low temperature formation of copper rich silicides. — Intermetallics 107, 108-115., https://doi.org/10.1016/j.intermet.2019.01.010

DóDOnY, I. 1976 : Crystal structures and genetical studies on the Palygorskite-Sepiolite-Saponite (Montmorillonite) group. — 7 th Conference on Clay Mineralogy and Petrology, September 28 - October 3, 1976, Karlovy Vary, Coll. Abstracts.

DóDONY, I. 1979a: Rétegszerkezetű szilikátásványok. - XI. Magyar Elektronmikroszkópos és Mikroanalízis Konferencia, 1979. augusztus 29 - szeptember 1., Szeged.

DóDony I. 1979b: HRTEM study of Zinckenite $\mathrm{PbSb}_{2} \mathrm{~S}_{4}$. - Proceedings of the 11th Soviet All-Union Confreence on Electron Microscopy, Tallin, October 1979, Izv. Akad. Nauk. SSSR (Ser. Fiz.) or Bull Acad.Sci. USSR (Phys Ser.) 44 (1980) Nos. 6 and 10.

DóDONY I. 1979c: Real structure of Ottrelite and unusual Chrysotile in HRTEM. - XII. All Union Conference on Electron Microscopy, Tallin, Collected Abstracts.

DóDONy, I. 1980: HRTEM study of Dioptase and Cu-Wollastonite. — International Mineralogical Association, Collected abstracts, 12th General Meeting, Orleans, France (July 4-6, 1980), p. 102.

Dódony, I. 1982: High Resolution Transmission Electron Microscopical Study of Polytipism in Stilpnomelane. - In: CsANÁDY, A., RöHLICH, P. \& SzABÓ, D. (eds): Abstracts booklet. 5th Multinational Philips Conference on the Application of Electron Microscopes for Research in Biology, Medicine and Technology, Visegrád, 1-2 April 1982. 
DóDONY I. 1985: Példák a TEM ásványtani kutatásokban való alkalmazására. — In: GATTER I. (szerk.): Ásványtan-geokémiai szemelvények. MFT kiadvány, Budapest, 3-18.

Dódony I. 1985: Milyenek a cinkszulfid ásványok? — Ásványgyújtő Figyelö 2, 4-11.

DóDony I. 1986: A wehrlit meghatározása. — Ásványgyújtó Figyelö 2, 26-37.

DóDONY I. 1987: A gyöngyösoroszi antimonit ásványtani újdonság. —- Ásványgyújitő Figyelő 3, 19-24.

Dódony, I. 1993: Microstructures in serpentinites. - Microscopia Elettronica 14 Suppl., 249-252.

DóDOnY, I. 1997a: Theoretical derivation and identification of possible two-layered lizardite polytypes. — In: MERLINo, S. (ed.): Modular Aspects of Minerals. EMU Notes in Mineralogy 1. Eötvös University Press, 57-80., https://doi.org/10.1180/emu-notes.1.3

DóDONY, I. 1997b: Structure of the 30-sectored polygonal serpentine. A model based on TEM and SAED studies. - Physics and Chemistry of Minerals 24, 39-49., https://doi.org/10.1007/s002690050015

DódONY, I. \& BALOG, A. 1982: Mineralogical study on vaterite and other related minerals of thermal water origin. - Annales Universitatis Scientiarum Budapestinensis de Rolando Eotvos Nominatae 24, 63-71.

Dódony, I. \& Buseck, P. R. 2001: Polysomatism and modules of gehlenite composition and structure in the Hanic phase $\left(\mathrm{Ca}_{5} \mathrm{Al}_{6} \mathrm{MgSiO}_{17}\right)$. - Physics and Chemistry of Minerals 28, 428-434., https://doi.org/10.1007/s002690100164

Dódony I. \& Buseck, P. R. 2004a: Serpentines close-up and intimate: An HRTEM view. — International Geology Review 46, 507-527., https://doi.org/10.2747/0020-6814.46.6.507

DÓDONY, I. \& BUSECK, P. R. 2004b: Lizardite-chlorite structural relationships and an inferred high-pressure lizardite polytype. American Mineralogist 89, 1631-1639., https://doi.org/10.2138/am-2004-11-1207

DóDONY I, \& CORA I. 2014: Elektron-krisztallográfia a krisztallográfia nemzetközi évében. — Fizikai Szemle 10, 347-351.

Dódony, I. \& Kiss, J. 1976: Crystal Structures and Genetical studies on the Palygorskite-Sepiolite-Saponite (Montmorillonite) group. - Acta Geologica Hungarica 20, 1-17.

DóDony, I. \& Lovas, A. Gy. 1980: HRTEM study of Dioptase $\mathrm{CuSiO}_{3} \times \mathrm{H}_{2} \mathrm{O} .-$ X. Hungarian Diffraction Conference, 25-30 April, 1980 Balatonaliga. Collected Abstracts.

DóDONy, I. \& Lovas, A. Gy. 1982: HRTEM study of Pseudowollastonite and Wollastonite. — XII. Magyar Elektronmikroszkópos és Mikroanalizis Konferencia, Eger, Kivonatok p. 21

Dódony, I. \& Lovas, A. Gy. 1982: Real structure of Pyrosmalite. - Proceedings of the 13th General Meeting of the International Mineralogical Association (IMA): Varna, September 19-25, 1982., p. 436.

DóDONY, I. \& Lovas, A. Gy. 1983: HRTEM study of Pseudowollastonite and Wollastonite. — Mikroskopie 40, 140-154.

DóDony, I. \& MALEev, M. 1984: Chain periodicity fault terminations in Rhodonite. — Proceedings of the Eighth European Congress on Electron Microscopy. 13 to 18 August 1984, Budapest 2., 1027-1028.

DóDONY, I. \& PóSFAI, M. 1989: Polymorphism of 4C and 5C pyrrhotites. - Zeitschrift für Kristallografie Suppl. 2, p. 55.

DóDONY, I. \& PósfaI, M. 1990: Polymorphism of pyrrhotite, Part II. A TEM study of 4C and 5C polymorphs. — European Journal of Mineralogy 2, 529-535., https://doi.org/10.1127/ejm/2/4/0529

Dódony, I. \& Soós, M. 1984: Crystallochemical relations in the mica-illite serial. — Proceedings of the Eighth European Congress on Electron Microscopy. 13 to 18 August 1984, Budapest 2., 1031-1032.

Dódony, I. \& Soós, M. 1986: A new member of the biopiribole. Recskite. - CBGA, Krakow, Abstracts

Dódony, I. \& TAKÁcs, J. 1980: Structure of precious opal from Cervenica. — Annales Universitatis Scientiarum Budapestinensis de Rolando Eotvos Nominatae 22, 37-50.

DóDONY, I. \& TAKÁCs, J. 1982: The structural and chemical study of Galena with low Sb content. — Proceedings of the 13th General Meeting of the International Mineralogical Association (IMA): Varna, September 19-25, 1982. p. 67.

DóDONY, I. \& TAKÁCS, J. 1986: Play of colours of noble opal in Vörösvágás. — Natura Borsodiensis 7-20.

Dódony, I. \& Weiszburg, T. 1979: Crystal structure of Wad in HRTEM. - XII. All Union Conference on Electron Microscopy, Tallin, Collected Abstracts.

Dódony, I. \& WeISZBurg, T. 1982: The structure of a "Wad" sample from Dognacea (Rumania). — Annales Universitatis Scientiarum Budapestinensis de Rolando Eotvos Nominatae 24, 53-62.

DóDony, I. \& WeIsZBuRg, T. 1983: The real structure of Ludwigite. — Mikroskopie 40, 140-154.

Dódony, I., Dimov, V. \& Lovas, A. Gy. 1984: Polytypism of Chloritoid: A new three-layered modification. — Proceedings of the Eighth European Congresson Electron Microscopy. 13 to 18 August 1984, Budapest 2., 1029-1030.

Dódony, I., Halász, I., Kirschner, I., Zsolt, G., Porjesz, R., Kovács, Gy, PorJesz, T. \& KÁrmán, T. 1991: TEM Investigations on Phases of Ceramic Samples of the Tl-Ca-Ba-Cu-O System. - Periodica Polytechnica 34, 335-342.

DóDONY, I., LovAS, A. Gy. \& Soós, M. 1994a: XRD and TEM study of the anisotropy of an anomalous grandite garnet from Recsk, Mátra Mts. (N Hungary). — Material Science Forum 166-169, 637-642., https://doi.org/10.4028/www.scientific.net/msf.166-169.637

Dódony, I., Lovas, A. Gy. \& Soós, M. 1994b: Anomalous grandite garnet from Recsk, Mátra Mts. (North Hungary). — Acta Mineralogica-Petrographica 35, 33-45.

DóDONY, I., PÓSFAI, M. \& BUSECK, P. R. 1996: Structural relationship between pyrite and marcasite. — American Mineralogist 81, 119-125., https://doi.org/10.2138/am-1996-1-215

DóDOnY, I., PóSFAI, M. \& BuSECK, P. R. 2002: Revised structure models for antigorite: A HRTEM study. — American Mineralogist 87, 1443-1457., https://doi.org/10.2138/am-2002-1022

Dódony, I., NÉmeth, P. \& Belluso, E. 2003: Vesuvianites and garnets from the Szár Hill, Polgárdi, Hungary. — Topographia Mineralogica Hungariae 8, 115-134.

Dódony, I., PósfaI, M. \& Buseck, P. R. 2006: Does antigorite really contain 4- and 8-membered rings of tetrahedra? - American Mineralogist 91, 1831-1838., https://doi.org/10.2138/am.2006.1971 
Dódony, I., PekKer, P. \& CoRA, I. 2012: Structural study of a kaolinite single-crystal using PED and diffraction tomography. — Acta Mineralogica-Petrographica, Abstract Series 7, p. 39.

FlanNigAn DAVID J. \& LindENBERG AARON M. (eds) (2018: Atomic-scale imaging of ultrafast materials dynamics. — MRS Bulletin 43/7, 485-490., https://doi.org/10.1557/mrs.2018.146

Galindo, P. L., Kret, S., Sanchez, A. M., Laval, J-Y., Yanez, A., Pizarro, J., Guerrero, E., Ben, T. \& Molina, S. I. 2007: The Peak Pairs algorithm for strain mapping from HRTEM images. — Ultramicroscopy 107, 1186-1193.

Hagberg, J., Lahderanta, E., Zsolt, G., Leppavuori, S., Kirschner, I., Laiho, R., Uusumaki, A., Porjesz, T., Dódony, I., Kovács, Gy., Levoska, J. \& KÁRMÁN, T. 1990: Hyper-diamagnetism in Bi(Pb)-Ca-Sr-Cu-O thick film. — Journal of Less-Common Metals 164165, 730-738., . https://doi.org/10.1016/0022-5088(90)90282-o

HAWKES, P. W. \& SPENCE, J. C. H. (eds) 2019: Springer Handbook of Microscopy. — Springer Verlag, 674 p., https://doi.org/10.1007/978 3-030-00069-1

IIJIMA, S. 1975: Ordering of the point defects in nonstoichiometric crystals of $\mathrm{Nb}_{12} \mathrm{O}_{29}$ - - Acta Crystallographica A 31, $784-790$.

Johan, Z., Dódony, I., MoráveK, P. \& PASAVA, J. 1994: La buchornite, $\mathrm{Pb}_{2} \mathrm{AuBiTe}_{2} \mathrm{~S}_{3}$, du gisement d’or de Jílové, République tchéque. Buckhornite, $\mathrm{Pb}_{2} \mathrm{AuBiTe}_{2} \mathrm{~S}_{3}$, from Jilove gold deposit, Czech Republic. — Comptes Rendus de l'Académie des sciences Paris 318/II, 1225-1231.

Kármán, T., Lahderanta, E., Leppavuori, S., Halász, I., Dódony, I., Zsolt, G., Porjesz, T., Laiho, R., Uusimaki, A., Kirschner, I. \& Kovács, Gy. 1990: Observation of a diamagnetic signal up to $132 \mathrm{~K}$ in a Tl-Ca-Ba-Cu-O compound. — Zeitschrift für Physik B Condensed Matter 78, 169-175., https://doi.org/10.1007/bf01307832

Kirschner, I., Leppavuori, S., Laiho, R., Uusimaki, A., Porjesz, T., Hagberg, J., Dódony, I., Lahderanta, E., Zsolt, G. \& Kovács, Gy. 1990: Parameters of High Temperature Hyper-Diamagnetism Observed in Bi-Based Superconduc-ting Thick Films. — XIX. International Conference on Low Temperature Physics, AD.P25, Brighton.

Kirschner, I., Leppavuori, S., Laiho, R., Altfeder, I., Dódony, I. Uusimaki, A., Porjesz, T., Hagberg, J., Kovács, Gy., Lahderanta, E., Volodin, A. \& Zsolt, G. 1991: Electrical and magnetic properties of variously annealed $\mathrm{Bi}(\mathrm{Pb})-\mathrm{Sr}-\mathrm{Ca}-\mathrm{Cu}-\mathrm{O}$ thick films. Zeitschrift für Physik B Condensed Matter 85, 175-186., https://doi.org/10.1007/bf01313218

KIRSCHNER, I., LEPPAVUORI, S., BODI, S. \& DóDONY, I. 1992: Direct measurement of inhomogeneous superconducting-normal transition in high Tc compounds. - World Congress on Superconductivity: Proceedings of the 3rd International Conference and Exhibition, 15-18 September 1992, Munich, Germany.

Kirschner, I., Bódi, A. C., Leppavuori, S., Uusimaki, A., Dódony, I. \& PorJesz, T. 1993a: Tracing of the effect of thermal cycling by thermometric mapping method in $\mathrm{Y}-\mathrm{Ba}-\mathrm{Cu}-\mathrm{O}$ superconductors. — Physics Letters A 178, 315-319., https://doi.org/10.1016/03759601(93)91108-h

Kirschner, I., Leppavuori, S., Bódi, A. C., UusimaKi, A. \& Dódony, I. 1993b: Direct measurement of inhomogeneous superconductingnormal transition in high-Tc compounds. — Applied Superconductivity 1, 1721-1726., https://doi.org/10.1016/0964-1807(93)90320-2

KNoll, M. \& RusKa, E. 1932: Das Elektronenmikroskop. — Zeitschrift für Physik 78, 318-339

Konishi, H., DóDony, I. \& Buseck, P. R. 2002: Protoanthophyllite from three metamorphosed serpentinites. — American Mineralogist 87, 1096-1103., https://doi.org/10.2138/am-2002-8-906

Konishi, H., Groy, T. L., Dódony, I., Miyanaki, R., Matsubara, S. \& Buseck, P. R. 2003: Crystal structure of protoanthophyllite: A new mineral from the Takase ultramafic complex, Japan. — American Mineralogist 88/11-12, 1718-1723., https://doi.org/10.2138/am-2003$11-1212$

KovÁcs Kis, V. \& Dódony, I. 1999: Structural disorder in natural cubic HgS. — Acta Mineralogica-Petrographica 40, 3-10.

Kovács Kis V. \& Dódony I. 2003: A túzkő ásványtani és kristályszerkezeti vizsgálata. — Földtani Közlöny 133, $309-323$.

Kovács KIS, V. \& DóDony, I. 2004: Mineralogical study of fibrous microcrystalline silica: chalcedony from Gyöngyössolymos, Northern Hungary. - Acta Mineralogica-Petrographica 45, 101-106.

Kovács Kis, V., Horvat, M. \& Dódony, I. 2004: Microstructures in Two Alkali Feldspar Megacrysts from the Papuk Mt., Croatia. Geologia Croatica 57, 149-158.

Kovács Kis, V., Dódony, I. \& LÁBÁR, J. L. 2006: Amorphous and partly ordered structures in $\mathrm{SiO}_{2}$ rich volcanic glasses. An electron diffraction study. — European Journal of Mineralogy 18/6, 745-752., https://doi.org/10.1127/0935-1221/2006/0018-0745

LÁBÁR, J. L., ADAMIK, M. \& DódONY, I. 1998: Contamination in analitical alectron microscopy and in ALCHEMI. — Microchimica Acta 15, 65-71., https://doi.org/10.1007/978-3-7091-7506-4_8

LÁBÁR, J. L., MorgIEL, J., TóTH, L. \& DóDONY, I. 2000: Sites are separable in garnets with ALCHEMI. — Mikrochimica Acta 132, 489492., https://doi.org/10.1007/s006040050098

Leppavuori, S., Kirschner, I., Uusimaki, A., Porjesz, T., Kovács, Gy., Dódony, I., Laiho, R. \& Zsolt, G. 1992: Comparison of superconductive parameters of variously prepared and treated thin films. — In: CORRERA, L. (ed.): High Tc superconductor thin films. 581-586., https://doi.org/10.1016/b978-0-444-89353-6.50094-4

Lovas, Gy. A. \& Dódony, I. 1997: A structural study on szaibélyite from its type-locality (Rézbánya, Bihar Mts., Rumania). — Acta Mineralogica-Petrographica 37 Suppl., 89-99.

Lovas, Gy. A., Dódony, I., Pöppl, L. \& SzALler, Zs. 1998: On the phase transitions of $\mathrm{Bi}_{2} \mathrm{Te}_{4} \mathrm{O}_{11}$ - - Journal of Solid State Chemistry 135, 175-181., https://doi.org/10.1006/jssc.1997.7594

Lovas, Gy., Dódony, I., Braun, T. \& Rausch, H. 1999a: The form of sulphur inpurity in commercial C 60 . — Magyar Kémiai Folyóirat 105, 363-371.

Lovas, Gy., Dódony, I., Braun, T. \& Rausch, H. 1999b: The form of sulphur inpurity in commercial $\mathrm{C}_{60}$. - Fullerene Science and Technology 7, 855-870., https://doi.org/10.1080/10641229909351383

MENYHÁRt A., DóDONY I. \& PEKKER P. 2011: Új ásványtani adatok a Mád környéki savanyú vulkanitokból. (Tokaji-hegység). — Földtani Közlöny 141/3, 257-266. 
Mindszenty, A., GalácZ, A., Dódony, I. \& CROnan, D. S. 1986: Paleoenvironmental significance of ferromanganese oxide concretions from the Hungarian Jurassic. —Chemie der Erde 45, 177-190.

NÉmeth, P., Dódony, I., Pósfai, M. \& Buseck, P. R. 2013: Complex Defect in Pyrite and Its Structure Model Derived from Geometric Phase Analysis. — Microscopy \& Microanalysis 19, 1-5, https://doi.org/10.1017/S1431927613001839

Németh, T., Máthé, Z., Pekker, P., Dódony, I., Kovács-Kis, V., Sipos, P., CorA, I. \& Kovács, I. 2016: Clay mineralogy of the Boda Claystone Formation (Mecsek Mts., SW Hungary). — Open Geosciences 8, 259-274., https://doi.org/10.1515/geo-2016-0024

ORMÁNDI, Sz. \& DóDONY, I. 2016: Synthesis and structural study of the Linde Type-A zeolite prepared from kaolinite. — Zastita Materijala 57/4, 565-570., https://doi.org/10.5937/zasmat1604565o

PAPP G., Dódony I., Földvári M. \& Lovas Gy. 1999: A dunabogdányi „hidroantigorit”. — Topographia Mineralogica Hungariae 6, 127-136.

Pennycook, T. J., Martinez, G. T., Nellist, P. D. \& Meyer, J. C. 2019: High dose efficiency atomic resolution imaging via electron ptychography. - Ultramicroscopy 196, 131-135., https://doi.org/10.1016/j.ultramic.2018.10.005

Petró, J., BótA, A., LÁszló, K., Beyer, H., KÁlmán, E. \& Dódony, I. 2000: A new alumina-supported, not pyrophoric Raney-type Nicatalist. - Applied Catalysis A: General 190, 73-86., https://doi.org/10.1016/s0926-860x(99)00267-7

PÓSFAI M. 2016: Nano-mozaik. — In: HoRn J. (szerk.): Életutak. Bányász Kultúráért Alapítvány, Budapest, 261-304.

Pósfai, M. \& Dódony, I. 1990: Polymorphism of pyrrhotite, Part I.: Fundamental structures of NC (N =2, 3, 4 and 5) types. - European Journal of Mineralogy 2, 525-528., https://doi.org/10.1127/ejm/2/4/0525

Raush, H., Dódony, I., Lovas, Gy. \& BRAUn, T. 1999a: Determination of sulphur as an impurity in commercial $\mathrm{C}_{60}$ soot and sublimated $\mathrm{C}_{60}$ polycrystals by INAA. - Magyar Kémiai Folyóirat 105, 229-233.

RAUSH, H., BRAUn T., DóDONY, I. \& Lovas, Gy. 1999b: Determination of sulphur as an impurity in commercial C60 soot and sublimated C60 polycrystals by INAA. — Analyst 124, 417-419., https://doi.org/10.1039/a808657e

Rauch, E. F., Portillo, J., Nicolopoulos, S., Bultreys, D., Rouvimov, S. \& Moeck, P. 2010: Automated nanocrystal orientation and phase mapping in the transmission electron microscope on the basis of precession electron diffraction. Zeitschrift für Kristallographie 225, 103-109. https://doi.org/10.1524/zkri.2010.1205

Rontó, V., Sólyom, J., KovÁcs, Á., PekKer, P. \& Dódony, I. 2013: Microstructure and phase analysis by TEM in Cu-Hf-Ti alloys. Materials Science Forum 729, 266-271., https://doi.org/10.4028/www.scientific.net/msf.729.266

Ruska, H., vON BorRIES, B. \& RUSKA, E. 1939: Die Bedeutung der Übermikroskopie für die Virusforschung. — Archiv für die gesamte Virusforschung 1/1, 155-169.

Schaffer, B., Schaffer, M., Ramasse, Q., Azough, F., Abou-Ras, D., Maclaren, I. \& Craven, A. 2011: Application of atomically resolved EELS mcted apping and HAADF imaging in aberration corrected STEM. - 10 ${ }^{\text {th }}$ Multinational Congress on Microscopy September 4-9, 2011, Urbino, Italy, 15-16.

SiPos, P., NÉMETH, T., MoHAI, I. \& DóDONY, I. 2005: Effect of soil composition on adsorption of lead as reflected by a study on a natural forest soil profile. — Geoderma 124, 363-374., https://doi.org/10.1016/j.geoderma.2004.05.011

Skarnulis, A. J., Iijima, S. \& Cowley, C. M. 1976: Refinemet of the Defect Structure of " $\mathrm{GeNb}_{9} \mathrm{O}_{25}$ " by High-Resolution Electron Microscopy. — Acta Crystallographica A 32, 799-805., https://doi.org/10.1107/s0567739476001630

Soós, M. \& DóDOnY, I. 1989: A TEM study of "orthopyroxene" from a lherzolite nodule. — Zeitschrift für Kristallografie Suppl. 2, p. 157.

Soós, M., Jánosi, M., Dódony, I. \& Lovas, G. 1991: Anomalous grandite garnet from Recsk, Mátra Mts. (N Hungary) Part.I. Chemical composition, optical and diffraction properties. — Neues Jahrbuch für Mineralogie Monatchefte 2, 76-86.

StADELMANN, P. A. 1987: EMS-A Softvare Package for Electron Diffraction Analysis and HREM Image Simulation in Material Science. — Ultramicroscopy 21, 131-146. https://doi.org/10.1016/0304-3991(87)90080-5

SzaKáll, S., Molnár, F., KovÁcs, Á. \& DóDOnY, I. 1994b: A telkibányai ércesedés szulfidásványai. — Topographica Mineralogica Hungariae 2, 149-179.

SZAKÁLl S., DódONY I. \& KovÁCS Á. 1994a: A telkibányai ércesedés halogenidjei. — Topographica Mineralogica Hungariae 2, $253-257$.

SzAKÁll S., Kovács Á. \& DóDONy I. 1995: Volframásványok a nagybörzsönyi ércesedésből. — Folia Historico Naturalia Musei Matraensis 20, 5-12.

SZAKÁLl S., FöLDVÁRI M. \& DóDONY I. 1997: Karbonáthidroxilapatitos ásványparagenezis az Esztramos-hegyről. — Topographia Mineralogica Hungariae 5, 123-130.

SZAller, Zs., PöPPL, L., Lovas, Gy. \& Dódony, I. 1996: Study of the formation of $\mathrm{Bi}_{2} \mathrm{Te}_{4} \mathrm{O}_{11}$ - - Journal of Solid-State Chemistry 121, 251-261., https://doi.org/10.1006/jssc.1996.0036

Uusimaki, A., Kirschner, I., Levoska, J., Hagberg, J., Zsolt, G., Kovács, Gy., Porjesz, T., Dódony, I., Leppavuori, S. \& Laiho, R. 1990: Relationship between microstructure and critical parameters in high Tc superconducting $\mathrm{Bi}-\mathrm{Pb}-\mathrm{Sr}-\mathrm{Ca}-\mathrm{Cu}-\mathrm{O}$ thick films. Cryogenics 30, 593-598., https://doi.org/10.1016/0011-2275(90)90290-s

VoGL M. 1981: Az agyagásványok vizsgálati módszereinek hazai fejlődése az elmúlt 20 év alatt. — Földtani Közlöny 111, 31 -39.

WANG, Y. X., LIU, P. \& QIN, G. W. 2015: Strain analysis of misfit dislocations in $\alpha-\mathrm{Fe}_{2} \mathrm{O}_{3} / \alpha-\mathrm{Al}_{2} \mathrm{O}_{3}$ heterostructure interface by geometric phase analysis. - Micron 69, 21-24., https://doi.org/10.1016/j.micron.2014.11.001

WenK, H.-R. (Coord. ed.) 1976: Electron Microscopy in Mineralogy. — Springer Verlag Berlin, Heidelberg, New York, 564 p. https://doi.org/10.1007/978-3-642-66196-9

Zega, T. J., Garvie, L. A. J., Dódony, I. \& Buseck, P. R. 2004: Serpentine nanotubes in the Mighei CM chondrite. — Earth and Planetary Science Letters 223, 141-146.

Zega, T. J., Garvie, L. A. J., Dódony, I., Friedrich, H., Stroud, R. M. \& Buseck, P. R. 2006: Polyhedral serpentine grains in CM chondrites. — Meteoritics and Planetary Science 41, 681-688., https://doi.org/10.1111/j.1945-5100.2006.tb00984.x 
Zou, X. 2005: What is Electron Crystallography? — In: WeIrich, T. E., LÁBÁR, J. L. \& XiAodong, Z. (eds): Electron Crystallography. Verlag Berlin, Heidelberg, New York, 3-16., https://doi.org/10.1007/1-4020-3920-4_1

Kézirat beérkezett: 2020. 03. 25. 